\title{
An Application of Geographic Information System to Identify the Suitability of Sea Cucumbers (Holothuria scabra) in West Lombok Waters
}

\author{
Laily Fitriani Mulyani ${ }^{1 *}$, Marsoedi², Guntur ${ }^{2}$ \\ ${ }^{1}$ Master Program of Fisheries and Marine Sciences Faculty of Fisheries and Marine Sciences, University of Brawijaya, \\ Malang, Indonesia \\ ${ }^{2}$ Faculty of Fisheries and Marine Sciences, University of Brawijaya, Malang, Indonesia
}

\begin{abstract}
This study was conducted on $17^{\text {th }}$ October $-27^{\text {th }}$ November 2016 at Gili Asahan, Gili Layar, and Gili Gede in West Sekotong, Lombok, West Nusa Tenggara. The purpose of this study was to analyze a suitable area for sea cucumber (Holothuria scabra) cultivation. Data collection had been done by survey method, acquiring primer and secondary data directly related to sea cucumber's life and analyzed by using ArcGIS software. A biological parameter for completing data of West Lombok Waters consisted of sandy mud, rocks, sand and rubble, chlorophyll-a 0.15-0.27 mg. $\mathrm{m}^{-3}$, and biomass cucumbers of 1-7 individuals. Land suitability classes were determined by the class interval, namely, S1 (27-33), S2 (20-26) and $N$ (13-19). Based on the results of scoring that has been adapted to the class interval, this project obtained sample points with a very suitable category (S1), namely, $A_{1}, A_{2}, A_{3}, B_{3}, C_{1}, C_{2}, C_{3}$. For the corresponding category (S2), there were $C_{4}$ and $C_{5}$. Finally, unreliable categories have been found in sample points $B_{1}$ and $B_{2}$.
\end{abstract}

Keywords: GIS, Land Suitability, Sea Cucumber, West Lombok Waters.

\section{INTRODUCTION}

Sea cucumbers are a group of invertebrate animals of the phylum of Echinodermata and class of Holothurioidea [1]. Sea cucumbers include important components in the food chain because of it is a deposit feeder and suspended feeder. Ecologically, sea cucumbers helps the process of decomposition of organic matter present in the sediment and release or produce nutrients into the food chain [2]. The Sea cucumbers include animals in the category of Appendix II of CITES, the population continues to decline every year. One effort to maintain this resource by restocking. Therefore, sustainable management to determine the suitable region is needed. Adequate information is necessary, which can be used for sea cucumber management in a sustainable manner.

Lombok Island is one of the hot spot of marine creature, and many of them is important component of marine-based tourism. The rapid development of tourism has been reported influence the marine creature, including sea cucumber. The proper management of marine creature is one of the important aspects of sustainable and competitive tourism destination $[3,4]$. In the management aspect of sea cucumber, one method used is Geographic

\footnotetext{
${ }^{*}$ Correspondence address:

Laily Fitriani Mulyani

Email: lay.lee.If@gmail.com

Address: Faculty of Fisheries and Marine Science, University of Brawijaya, Veteran St. Malang 65145
}

Information System (GIS). GIS can facilitate in analyzing the data and determining the suitable cultivation area. Given the importance of the sea cucumber's function, good resources management is required. The purpose of this study was to analyze the suitability of cultivated area for Sea Cucumber (Holothuria scabra) in West Lombok based on biological parameters.

\section{RESEARCH METHOD}

The research location at Gili Asahan, Gili Gede, Gili Layar in Sekotong, Lombok, West Nusa Tenggara. This study was conducted $17^{\text {th }}$ October - $27^{\text {th }}$ November 2016 includes the necessary data collection and sampling were carried out directly on site. The method used in this study is a survey, which is collects data on the condition of the field in the West Lombok and the data were analyzed using geographic information system software.

Tools used are ships, clippers, sample's bottles, stationery, measuring cups, stopwatch, pipe, cameras, rope, board tide, GPS, thermometer, refractometer, $\mathrm{pH}$ meter, DO meter, secchi disk and current meter. Materials used are sea cucumbers, tissue, paper labels, alcohol, sample containers.

\section{Research Procedure}

Area of research conducted in the area of West Lombok. Western Digital Data of West Lombok Waters base map used to create thematic maps, then interpolation was applied for each parameter. Water conditions that will be 
measured are: substrate, chlorophyll-a and biomass of sea cucumber. Then made a map contours of the primary data for each parameter used as background for the digitization process so that every thematic maps divided by several classes. Furthermore, the condition of the map or the map contours analyzed by the overlay that combines multiple information on the map to generate a new information. Once the criteria is built and analyzed, it will eventually generate suitability maps of sea cucumber cultivation area.

\section{Spatial Analysis and Scoring Matrix Weighting}

Analysis of the suitability of sea cucumber cultivation areas carried by several techniques. First, the parameters which determine the suitability of land or very influential included in class S1 or highly customized and are still having a limiting factor. But if the area is still do farming activities included in the S2 class or suitable, and the area which have many limiting factors given in class N. parameters are very good for growing sea cucumbers are given the highest score.

\section{Overlay Analysis}

Overlay is combining several map information to generate new information, overlaying a spatial analysis capabilities that can be done effectively in GIS. The results of the spatial analysis is in the form of a map as to the suitability of sea cucumber cultivation area.

\section{RESULT AND DISCUSSION}

Parameters of observation in this study is a water-quality based on biological parameters, i.e.biomass of sea cucumber, chlorophyll-a and substrate (Table 1). The parameters are parameters that associated with the growing requirements of sea cucumbers which will be cultivated.

Table 1.Weighting Results and Scores Against Land Suitability Value for Each Parameter

\begin{tabular}{lcccc}
\multicolumn{5}{c}{ Suitability Value for Each Parameter } \\
\hline Parameter & Criteria & $\begin{array}{c}\text { Rating } \\
\text { Scale }\end{array}$ & Value & Score \\
\hline chlorophyll- & $3.5-10$ & 5 & 1 & 5 \\
a [5] & $0.2-<3.5$ & 3 & & 3 \\
& $<0.2$ & 1 & & 1 \\
\hline Substrate & sandy mud, & 5 & 3 & 15 \\
[6] & rocks and & 3 & & 9 \\
& sand & 1 & & 3 \\
\hline Biomass [7] & rubble & & & \\
& $>3$ & 5 & 3 & 15 \\
& $1-3$ & 3 & & 9 \\
& 0 & 1 & & 3 \\
\hline
\end{tabular}

Determining the condition of life adapted to the cultivation of cucumbers quality standards. Research carried out directly or through observation satellite image data which indicates the difference between the value of each sampling point. The point difference between the value adjusted with the quality standards of each parameter. The use of quality standards to facilitate the scoring rate of land suitability. Sampling point coordinates can be seen in Table 2.

Table 2. Sampling Point Coordinates

\begin{tabular}{lcccc}
\hline \multirow{2}{*}{ Location } & \multirow{2}{*}{ Station } & \multicolumn{2}{c}{ Coordinates Point } & \multirow{2}{*}{ Code } \\
\cline { 3 - 4 } Gili Asahan & 1 & $\mathbf{X}$ & $\mathbf{Y}$ & \\
& 2 & 377622 & 9033235 & $\mathrm{~A}_{1}$ \\
& 3 & 376152 & 9034368 & $\mathrm{~A}_{3}$ \\
\hline Gili Layar & 1 & 377890 & 9034520 & $\mathrm{~B}_{1}$ \\
& 2 & 379742 & 9034810 & $\mathrm{~B}_{2}$ \\
& 3 & 379053 & 9035314 & $\mathrm{~B}_{3}$ \\
\hline Gili Gede & 1 & 378543 & 9036539 & $\mathrm{C}_{1}$ \\
& 2 & 379868 & 9035539 & $\mathrm{C}_{2}$ \\
& 3 & 381168 & 9033738 & $\mathrm{C}_{3}$ \\
& 4 & 381647 & 9035211 & $\mathrm{C}_{4}$ \\
& 5 & 381700 & 9033972 & $\mathrm{C}_{5}$ \\
\hline
\end{tabular}

Biomass of Sea Cucumber

Observations of sea cucumber biomass or number of individuals of sea cucumbers at the study site obtained from the number of sea cucumbers in the lowest and the highest range as 1 and 7. There are two categories on the suitability of these observations, which are very suitable and suitable. The research areas which have a very suitable categories contained in the sample points $A_{1}, A_{2}, A_{3}, C_{1}, C_{2}, C_{3}, C_{4}$, and $C_{5}$. While the region has the suitable category contained in the sample points $B_{1}, B_{2}$, and $B_{3}$ where the number of sea cucumbers were obtained less than 3 individuals (Fig. 1).

\section{Substrates}

Observation of the substrate in the waters of West Lombok obtained sandy mud, sand, rocks, sand and rubble (Fig. 2). There are three categories on the suitability of the substrate observations, such as: very suitable, suitable and not suitable. Very suitable categories contained in the sample points $A_{1}, B_{3}, C_{2}$ and $C_{3}$. Then the suitable category contained in the sample points $A 2, A 3, C_{1}$ and $C_{4}$. While the category is not suitable there at the point $B_{1}, B_{2}$ and $C_{5}$.

\section{Chlorophyll-a}

Data obtained from the chlorophyll-a Aqua MODIS satellite data with the value of chlorophyll-a range of 0.15 to $0.27 \mathrm{mg} \cdot \mathrm{m}^{-3}$. The distribution of chlorophyll-a show that most of the sub-district has a small value of chlorophyll-a (Fig. 3). There are three categories of classes on 
observations of chlorophyll-a, to the suitable class (S2) is in Gili Asahan $\left(A_{1}, A_{2}, A_{3}\right)$, Gili Layar $\left(B_{1}\right)$ and Gili Gede $\left(A_{1}, A_{5}\right)$. For the category is not suitable $(N)$ is in Gili Layar $\left(B_{1}, B_{2}\right)$ and Gili Gede $\left(C_{2}, C_{3}, C_{4}\right)$.

\section{Region Suitability Cultivation}

Observations on biological parameter that includes a substrate, biomass and chlorophyll a of sea cucumber in the waters of West Lombokanalyzed using Geographic Information System (GIS). It produce thematic maps of aquaculture suitability of sea cucumber $(H$. scabra) based on biological parameters can be seen in Figure 4. Based on chemical parameters, the interpolation of visible West Lombok subdistrict is shown in green to red. The interpolation pattern shows that there are three categories of land suitability of sea cucumber aquaculture.

Land suitability classes are determined based on the interval between the other classes S1 (2733), S2 (20-26) and $N$ (13-19). Based on the results of scoring that has been adapted to the class interval obtained sample points with a very suitable category (S1) including $A_{1}, A_{2}, A_{3}, B_{3}, C_{1}$, $C_{2}, C_{3}$. Then for the corresponding category (S2) between $C_{4}, C_{5}$.

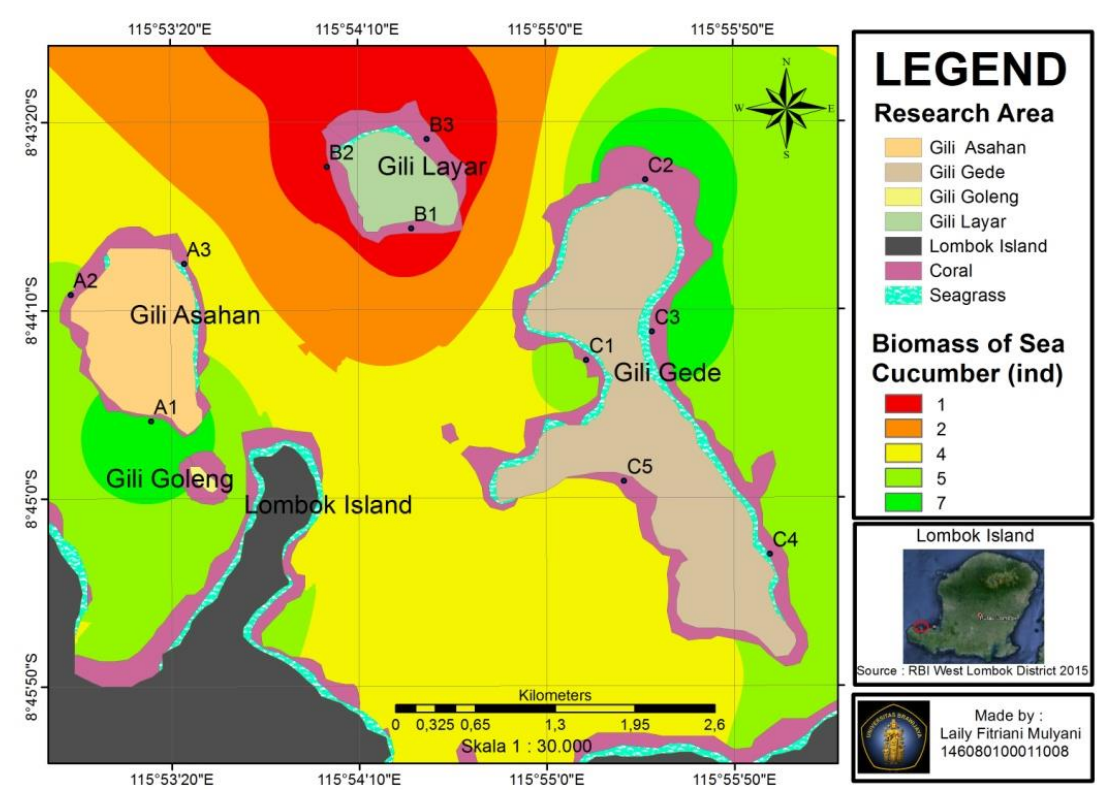

Figure 1. Biomass Distribution of Sea Cucumber in West Lombok Waters

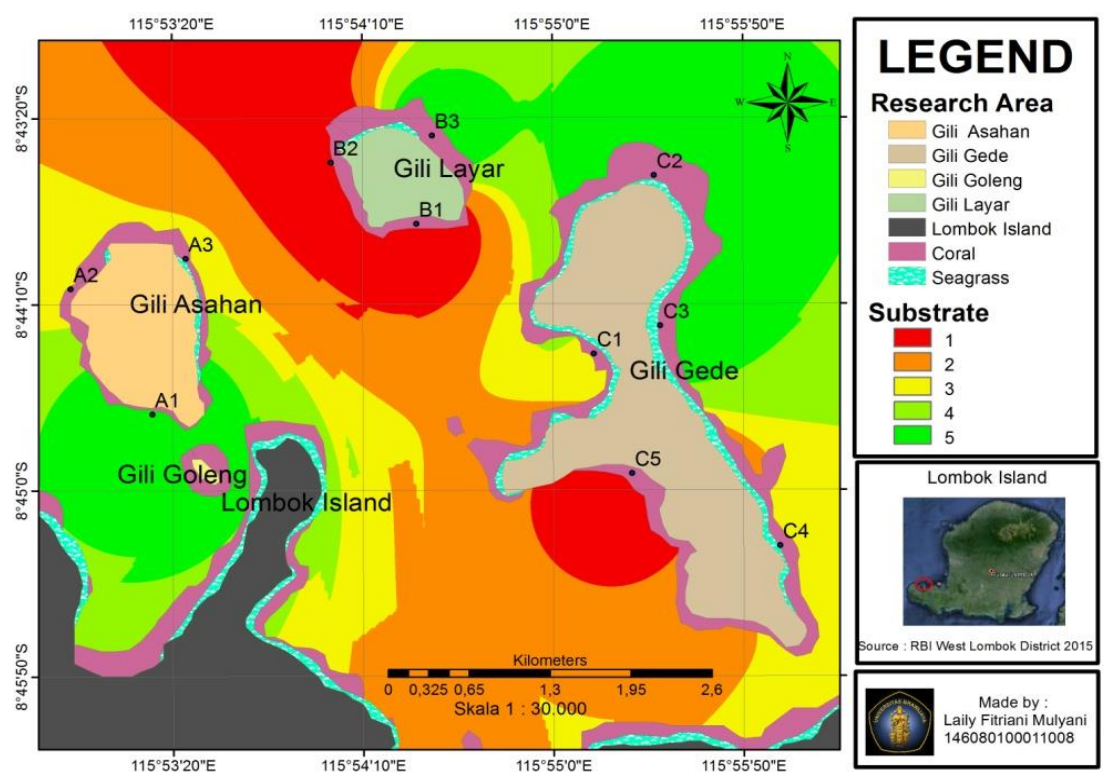

Figure 2. Distribution of Substrate in West Lombok Waters 


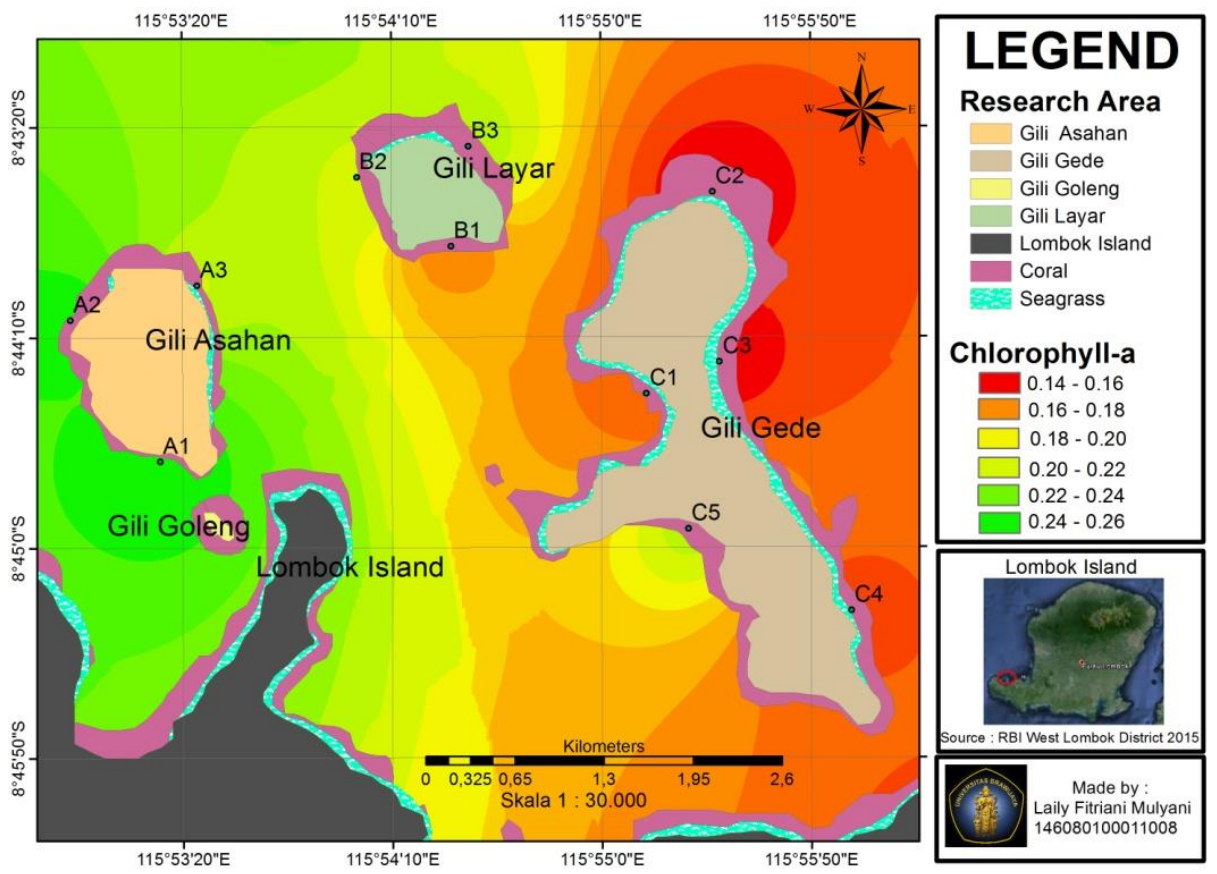

Figure 3. Distribution of chlorophyll-a in West Lombok Waters

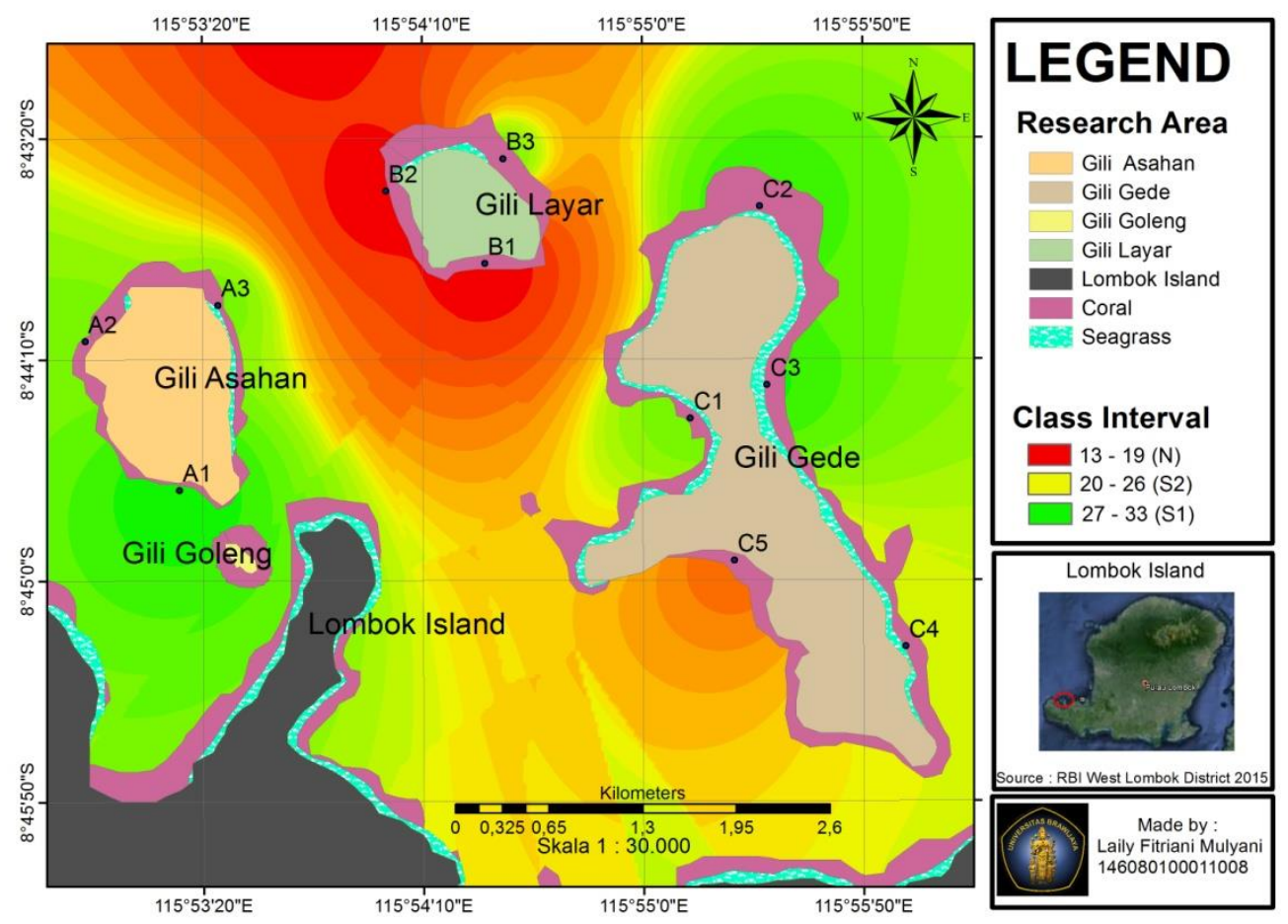

Figure 4. Overlay of Land Suitability Sea cucumbers (Holothuria scabra) Based on Biological Parameters.

Meanwhile, according to the category which is not contained sample is in points $B_{1}$ and $B_{2}$, where the sample point lies in Gili Layar. During the observation, sea cucumbers are found only slightly less than 8 individuals. This is in accordance with the statement of the Wildlife Conservation Society [8], the abundance of sea cucumbers in the waters of Lombok relatively very low, from 64 point surveys, the presence of sea cucumber found only in 10 point survey of Gili Asahan, Gili Gede, Gili Layar (West Lombok), Gili Lawang West, Gili Sulat east, Sapakoko east, Heaven on the Planet, Gili Maringki (East Lombok), West sire and Soraya Reef (North Lombok). The abundance of sea cucumbers were found less than 50 ind.ha-1. 
The least amount of $H$. scabra is because this animal is one type of high economic value of sea cucumbers, which are the main target of the hunt so that the population has been greatly reduced. In addition due to overfishing, the low number of individuals of $H$. scabra likely caused by the habit of immersing itself in the substrate, thus it was not detected during the observation.

Among the factors causing low density of sea cucumbers in a region is due to natural factors, namely support of the environment and way of life, which are solitary [6]. The natural density of sea cucumbers is closely connected with the carrying capacity of the environment. Overall seen that $H$. atra is found in all observation stations and the most dominating than other types of sand sea cucumber [9]. Holothuria atra was the most abundant species of sea cucumbers and very wide distribution in most of the IndoPacific region [10].

Most parts of Asia, sea cucumber fisheries have been overfished and the population of highvalue species such as $H$. fuscogilva, $H$. whitmaei, $H$. scabra and Thelenota ananas has been exhausted. The field survey also showed that some high-value sea cucumber species have also been heading for extinction in some areas in Indonesia, Vietnam, and the Philippines [11]. Most of the economic value of sea cucumber stocks have been exploited in excess so that the sea cucumber fishery began to shift toward lowvalue species of sea cucumber, as a result of increasing demand [12]. The impact of excessive exploitation of sea cucumbers is a decline in natural population stock, the smaller body size, and distribution in the deep [4].

Sea cucumber fishery has expanded rapidly in the tropical waters over the past decades due to high demand from international markets and the ease of capture in nature [13]. Given the slow movement, cause sea cucumber became the target hunts can easily be captured even though withoutuse tool. Sea cucumbers are caught by fishermen by means of a dive by hand [14]. Catching up with the dive way will certainly take a lot of effort and cost compared to arrests made in shallow waters and without diving.

Most people in the West Lombokare fishermen. One was a sea cucumber fisherman catcher. In one fishing, fishermen were able to catch sea cucumbers as much as 3-7 kg per trip. This condition is of course very dangerous for sea cucumber populations given the growing process from seedling stage to maturity running slow so that the stock of sea cucumbers in nature will slowly run out and can affect the lives of other biota, especially predators of sea cucumbers. Predatory sea cucumbers are invertebrates such as starfish, fish, crab, some gastropod species, birds, and turtles [15]. The predator sea cucumber is a large-sized starfish, crab of species Dardanus megistos, species Atergatis floridus and snail of species Tonna perdix [16].

The main factor reducing the stock of sea cucumbers in Indonesia allegedly was the result of over exploitation and habitat destruction by humans (anthropogenic pressures). The more dense a population and the more advanced region of the pressure posed for marine life, especially species of sea cucumbers are also higher. This led to several regions in Indonesia that conditions have been damaged and polluted waters as a result of this pressure, sea cucumber population declining and increasingly rare. Conversely, the lower the anthropogenic pressures on the water environment, the better the condition of its waters, including the organisms that live in it.

Overall, the parameters of aquatic environment in the form of sandy substrate greatly favored by all kinds of sea cucumbers while dusty and clayey substrate is avoided. The sea cucumber including members of the phylum Echinodermata commonly inhabit the sandy beach [17]. One pattern adaptations made by the inhabitants of aquatic organisms beach with sandy substrate is to immerse himself in the substrate. When the digging substrate biota, organic fine particles other than grains of sand will be digested in the body. The reason cucumbers avoid muddy substrate only because the substrate is a possibility of environmental anoxic or without oxygen [18]. Sea cucumbers may have difficulty in actuating the muddy substrate [19]. Sea cucumbers tend to concentrate in areas with high levels of organic matter [20]. Holothuria sanctori have food selectivity against sediment with high concentrations of organic matter. Consumption of organic material will increase with the increased availability of organic material [21].

\section{CONCLUSION}

The conclusion based on the results of research in the District West Lombok is the level of land suitability for cultivation Cucumber Sand in District West Lombok to the category of very suitable (S1) including $A_{1}, A_{2}, A_{3}, B_{3}, C_{1}, C_{2}, C_{3}$ with a range of scoring (27-33), for the corresponding category (S2) include $\mathrm{C}_{4}$ and $\mathrm{C}_{5}$ with the range of 
values scoring (20-26) and the category of not suitable $(N)$ between $B_{1}$ and $B_{2}$ with a range of values scoring (13-19). This research is a research stage plan for determining the location of the sand sea cucumber cultivation. It is need for further studies to determine the extent of the carrying capacity of the region to produce sand sea cucumbers.

\section{REFERENCES}

[1] Purcell, S. W., Y. Samyn and C. Conand. 2012. Commercially important sea cucumbers of the world. Food and Agriculture Organization of The United Nations. FAO Species Catalogue for Fishery Purposes No. 6. Rome.

[2] Darsono, P. 2003. Sumberdaya Teripang dan pengelolaannya. Oseana 28(2), 1-9.

[3] Hakim, L. 2004. Dasar-dasar Ekowisata. Bayumedia. Malang.

[4] Hakim, L., Soemarno and S. K. Hong. 2012. Challenges for conserving biodiversity and developing sustainable island tourism in North Sulawesi Province, Indonesia. Journal of Ecology and Environment 35(2), 61-71.

[5] Septian, I., H. Suherman and S. A. Harahap. 2014. Pemetaan kesesuaian perairan untuk budidaya rumput laut di Kepulauan Anabas Provinsi Kepulauan Riau. Jurnal Perikanan Kelauatan 5(2), 240-247.

[6] Purwati and A. Syahailatua. 2008. Timun Laut Lombok Barat. Ikatan Sarjana Oseanologi Indonesia (ISOI). Jakarta.

[7] Kordi, M. G. H. 2012. Cara gampang membudidayakan Teripang. Lily Publisher. Yogyakarta.

[8] WCS (Wildlife Conservation Society). 2014. Laporan Lembaga Perlindungan Cagar Alam KabupatenLombok Barat. Report. West Nusa Tenggara.

[9] Lee, J., M. Byme and S. Uthicke. 2008. The influence of population density on fission and growth of Holothuria atra in Natural Mesocosm. Journal of Experimental Marine Biology and Ecology 363, 126-135.

[10] Uthicke, S. 2001. Influence of asexual reproduction on the structure and dynamics of Holothuria atra and Stichopus chloronotus populations of The Great Barrier Reef. Marine and Freshwater Research 52, 205215.

[11] Choo, P. S. 2008. Population status, fisheries and trade of sea cucumbers in Asia. In: ToralGranda, V., A. Lovatelli, M. Vasconcellos (Eds). Sea cucumbers: a global review on fisheries and trade. FAO Fisheries and Aquaculture Technical Paper 516, 119-142.

[12] Conand, C. and N. Muthiga. 2008. Commercial sea cucumbers: a review for the Western Indian Ocean. WIOMSA Book Series 5, 66-72.

[13] Lovatelli, A., C. Conand, S. Purcell, S. Uthicke, J. F. Hamel and A. Mercier. 2004. Advances in sea cucumber aquaculture and management. FAO Fish Tech Paper No. 463. FAO, Rome.

[14] Dissanayake, D. C. T. and M. J. S. Wijeyaratne. 2007. Studies on the sea cucumber fishery inthe north western coastal region of Sri Lanka. Sri Lanka. Journal of Aquatic Science12, 19-38.

[15] Dance, S. K., I. Lane and J. D. Bell. 2003. Variation in short-term survival of cultured sandfish (Holothuria scabra) released in mangrove-seagrass and coral reef flat habitats in Solomon Islands. Aquaculture 220, 495-505.

[16] Azis, A. 1995. Beberapa catatan tentang Teripang Bangsa Aspidochirotida. Oseana 20(4), 11-23.

[17] Nybakken, J. W. 1992. Biologi laut. Suatu pendekatan ekologis. PT Gramedia Pustaka Utama. Jakarta.

[18] Mercier, A., S. C. Battaglene and J. F. Hamel. 2000. Settlement preferences and early migration of the tropical sea cucumber Holothuria scabra. Journal of Experimental Marine Biology and Ecology 249,89-110.

[19] Dissanayake, D. C. T. and G. Stefansson. 2012. Habitat preference of sea cucumbers: Holothuria atraand Holothuria edulis in the coastal waters of Sri Lanka. Journal of the Marine Biological Association of the United Kingdom92(3),581-590.

[20] Slater, M. J. and A. G. Jeffs. 2010. Do benthic sediment characteristics explain the distribution of juveniles of the depositfeeding sea cucumber Australostichopus mollis. Journal of Sea Research 64, 241-249.

[21] Navarro, G. Pablo Sanz, G. Sara and F. Tuya. 2014. Contrasting displacement of the Sea Cucumber Holothuria arguinensis between adjacent nearshore habitats. Journal of Experimental Marine Biology and Ecology 453,123-130. 